ПРЕЛИМИНАРНА САОПШТЕЊА

ПРЕДВАРИТЕЛЬНЫЕ СООБЩЕНИЯ

PRELIMINARY COMMUNICATIONS

\title{
STATIC ABSORBER MODELLING
}

\author{
Milica D. Đekić \\ Independent researcher, Subotica, Republic of Serbia, \\ e-mail: milicadjekic82@gmail.com, \\ ORCID iD: Dhttps://orcid.org/0000-0002-3962-5951
}

DOI: 10.5937/vojtehg70-34776; https://doi.org/10.5937/vojtehg70-34776

ARTICLE FIELD: Binary Logics, Applied Mathematics, Informatics,

Defense Industry, Computer Science, Electronics

ARTICLE TYPE: Preliminary communication

\begin{abstract}
:
Introduction/purpose: A static absorber is capable of neutralizing any signal either in the physical or virtual domain and its analysis will be presented in this paper.

Methods: The approach used here includes purely scientific thoughts as well as a model with its explanations evaluated step by step applying highly sophisticated computer tools for design and simulation. No empirical results will be attached, only claims with their evidence.

Results: The crucial outcome of this research is a completely new approach to binary systems that are now observed as a set of real numbers.

Conclusion: The purpose of this research is to introduce something brandnew that can be used in cyber industry while a dynamic variation of the absorber is still under development.
\end{abstract}

Key words: cyber defense, intelligence, static absorber, signal ban, hacking, singularity, mathematical modelling.

\section{Introduction}

The first applications of binary algebra started several decades ago. The entire mathematical concept is based on the set theory which deals with two basic elements: 0 and 1 . Engineers of the $20^{\text {th }}$ century discovered semiconductor technology that represents 0 and 1 as the definite voltage values: $0 \mathrm{~V}$ and $5 \mathrm{~V}$. In such a way, that paradigm has gotten its physical sense as in digital electronics where it deals with real electricity fields. The idea of the given mathematical model is quite simple and it relies on the fundamental and proven theorems of binary 
logics. This paper demonstrates a complete set of mathematical models, digital circuits, and truth tables as well as proofs that serve to illustrate a digital logic scheme being capable of neutralizing any signal or a set of signals coming to its input. In other words, whatever is given at the input will be made into 0 at its output. This is feasible as any signal being ANDed with its inverted variation is equal to 0 . Apparently, such a model can be assumed as a singularity in the voltage field and some testing graphs in such a context will be described. Also, this paper will introduce a completely new approach to binary algebra offering a chance to analyze such an energy area in a set of real numbers. In the essence, this modelling can serve in software and hardware production as there have been a lot of benefits from a static absorber that can be applied in cyber industry. Indeed, there have been a lot of pluses and minuses of such a solution and this article will address how to use its advantages and, consequently, avoid some drawbacks. (Djekic, 2020b), (Djekic, 2021e), (Djekic, 2021d)

In general, technology has always been a responsibility of the one who applies it and for such a reason it is important to appeal to everyone being in possession of something powerful to deal with it with selflessness, not selfishness.

It has been quite easy to pass by things without noticing anything. Once mankind has had an eye for details, it will progress much faster than ever. The nature is full of wonders that wait for humans to pay attention to them. Apparently, that is how the biggest discoveries in science were made. Next, there has been a question how well the current natural phenomena were explained and understood. For instance, it is well known that an original signal with its inversion at the input of the AND logic gate always gives 0 at the output. Boolean algebra can mathematically prove such a theorem and, indeed, digital electronics can provide these circuits to work accurately. Indeed, it has been necessary to sort things out intelligently in order to get their maximum performance. In other words, it is like testing the mathematical and logical IQ by attempting to fit the right shape object into the right opening. Another good question about such a theory could be: Where will all that energy go if anything at the input gives nothing at the output? It seems something has been very strange with such a circuit as it behaves like a singular point pulling everything inside. On the other hand, if that logic configuration were to behave like a sink, it would need better mathematical modelling to be better tackled. Also, there has been a strong need for computer simulations as well as experimental examinations in order to gain a deep insight into all scientific secrets. 
Humankind may not be at that degree of technological development at present, but the ongoing tendency suggests that the modern world could be on a good track to make a better use of current endeavors.

Next, there has been a sense of wonder how such a fundamental Boolean rule could serve in cyber security. The majority of the present IT security solutions are based on binary algebra. On the other hand, the marketplace is literally overwhelmed with highly expensive, but not that effective analytical tools. In other words, cyber defense analysts sitting in their security operating centers (SOCs) can recognize if anyone has been trying to make a breach and maintain connection with some network's device, but in order to protect their asset from such an attack they need to terminate that signal manually. It is an appealing message, is it not? In the $21^{\text {st }}$ century, something is still needed to be done with hands. How inconvenient?! Apparently, if it is feasible to recognize web's anomalies, it should be possible to terminate them automatically letting only trusted devices exchange the information with a well-protected grid. Indeed, there has been something which could absorb any signal and if there were an opportunity to pass only untrusted connections through that absorber, all unwanted behaviors would be banned in a sub-second period of time. No more breaches, right? At this stage, it is about how to prevent or probably reduce such a concern; however, if the right things are put into right places, the best possible performances are expected. (Djekic, 2017), (Đekić, 2021)

In a similar way, hackers can get a brilliant idea creating a malware that can neutralize the internet connectivity and put into quarantine any infected object. In total, everything is still an idea which can become a reality in the coming time.

The purpose of this idea is to improve the effectiveness of the incident response turning active defense into the passive one or, in other words - converting monitoring and incident responses into extremely intelligent prevention. There has been a need to develop a computer code very smartly so that it could differentiate trusted from untrusted behaviors on the web. (Djekic, 2021a), (Djekic, 2021b), (Djekic, 2021c)

Maybe it is not that much about artificial intelligence as it has been about allowing the communication through a well-developed algorithm that can make a decision, not think for real. Also, there is a need for antibreach software, where the attacker leaves an IP address, but cannot establish communication with a targeted device for being rejected any time an attempt occurs. In other words, it is a sort of communication filtering and quite good protection due to which cyber warfare could be history if appropriately applied. The entire concept can be imagined as 
the informatics body armor of cyber warriors that cannot be wounded or killed on their positions once they apply such a shield. The model is called static since it uses only logic gates without returning branches that could consist of some memory elements.

\section{Mathematical models using binary algebra}

The set theory is a well-developed and researched area of mathematics which has many applications in everyday life. On the other hand, there is binary algebra that deals with only two unique elements, 0 and 1 . Such a field of science has found many usages in electronics, especially digital, as the entire modern computer science applies the results of these explorations. In this research, it has been investigated how it is possible to do modelling of logic circuits without any dynamics applied to them in order to analyze and simulate their behavior excluding real experimental conditions and laboratory testing. Also, no coding has been done in this research as it presents an idea how to develop a code so far as mathematical modelling can contribute in making both hardware and software.

A basic static absorber can be obtained if original and inverted signals are settled at the input of the AND logic gate. The mathematical description is given in equation (1) as follows:

where:

$$
B=A \cdot \bar{A}
$$

$A$ - is an input to the AND logic gate which is in affirmation;

$\bar{A}$ - is an input to the AND logic gate which is in negation; and

$B$ - is an output of the AND logic gate with two inputs so far.

In other words, any combination at the input will give 0 at the output causing the signal to just disappear. This is given in equation (2) as follows:

$$
A \cdot \bar{A}=0
$$

where:

$A$ - is an input to the AND logic gate which is in affirmation and $\bar{A}$ - is an input to the AND logic gate which is in negation. 

follows:

This can be examined in the truth table that is given in Table 1 as

Table 1 - Truth table of the initial static absorber

Таблица 1 - Таблица истинности исходного статического абсорбера

Табела 1 - Истинитосна табела иницијалног статичког апсорбера

\begin{tabular}{|c|c|}
\hline A & B \\
\hline 0 & 0 \\
\hline 1 & 0 \\
\hline
\end{tabular}

Next, an illustration of the basic static absorber digital circuit will be provided. The illustration is made in Logic Circuit Designer software that can offer quite a reliable simulation option. Figure 1 is given as follows.

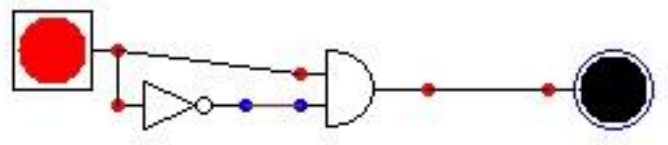

Figure 1 - Basic static absorber circuit

Puc. 1 - Базовая схема статического абсорбера

Слика 1 - Основно коло статичког апсорбера

The illustration represents the AND logic gate with 2 inputs which are, in this case, the original signal and its inverted version. If equations (1) and (2) are taken into consideration with their truth table (given in Table 1), it is quite obvious that the results of the simulation will be identical to the given mathematical description. In this case, such a model has gotten its proof and it is highly recommended that software developers make an attempt to create a program that can work as given through this modelling. Also, it is obvious that any entry at the input of this circuit will absorb the signal and give 0 as its output. Further, it will be explained why such a sort of mathematical models could be considered as a singularity as it literally neutralizes any electricity coming in. In other words, it can be discussed that everything given in equations (1) and (2) as well as in their truth table and logic diagram will be like a sink to 
anything at the input. The recommendation is to go deeper into the analysis of electronic circuits in order to completely understand such semiconductor technology as well as the behavior of the applied electronic elements. Digital electronics is a field with so many areas to investigate and at this stage there has been insufficient awareness about the opportunity that such a branch of science and technology can offer so far.

This paper will demonstrate how a slightly complicated model of the static absorber can be developed. In such a case, through simple mathematics and proof using truth tables and logic simulations, it will be shown how this model can find its applications in practice. From this standpoint, it is possible to begin with a mathematical model that relies on Boolean algebra and combines the AND, OR and NOT logic functions. The description of the model is given in equation (3) as follows:

$$
C=(A \cdot \bar{A})+(B \cdot \bar{B})
$$

where:

$A$ - is an input to the AND logic gate which is in affirmation;

$\bar{A}$ - is an input to the AND logic gate which is in negation;

$B$ - is an input to the AND logic gate which is in affirmation;

$\bar{B}$ - is an input to the AND logic gate which is in negation; and

$C$ - is an output of the OR logic gate that always gives nothing for a result as its inputs are always 0 .

As given in equations (1) and (2), something AND its inversion are always equal to nothing; so, if everything is submitted into equation (3), it will be continued with equation (4) as follows:

$$
C=0+0=0
$$

where:

$C$ - is an output of the OR logic gate that always gives nothing for a result as its inputs are always 0 .

In practice, the OR logic gate gives nothing only if all its inputs do not have a signal as their incoming value. Such modelling can serve in 
designing much complicated logic circuitries. Apparently, the real clues to this modelling can be obtained via equation (3) the truth table of which is given in Table 2 as follows:

Table 2 - Truth table of the complex static neutralizer

Таблица 2 - Таблица истинности комплексного статического нейтрализатора

Табела 2 - Истинитосна тебела комплексног статичког неутрализатора

\begin{tabular}{|c|c|c|}
\hline A & B & C \\
\hline 0 & 0 & 0 \\
\hline 0 & 1 & 0 \\
\hline 1 & 0 & 0 \\
\hline 1 & 1 & 0 \\
\hline
\end{tabular}

The truth table given above is the evidence of the well-developed mathematical model whose logic circuit is given in Figure 2 as follows:

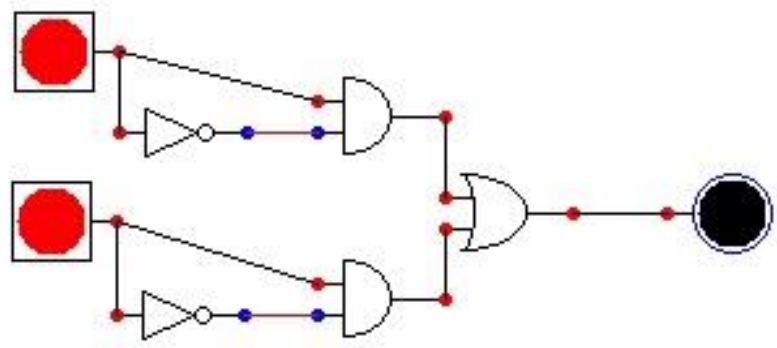

Figure 2 - Logic diagram of a complicated static absorber

Puc. 2 - Логическая схема сложного статического абсорбера

Слика 2 - Логички дијаграм компликованог статичког апсорбера

The static absorber is possible to be designed applying so simple and fundamental logic functions available in both hardware and software formats. The further research will try to handle a set of real numbers in order to examine all possibilities of an energetic field as well as some characteristics of semiconductor technology typical to silicon-based solutions. It will also introduce a kind of mathematical transformations from a set of binary numbers into a set of real numbers trying to invoke the entire new area of mathematics that could find its applications in future scientific research and explorations. In other words, it will be necessary to thoroughly understand the physical characteristics of digital 
technology since it can cope, as far as it is known at this stage, with the singular points in some scalar or vector fields, suggesting maybe that future investigations will need a better understanding of the field theory. At this stage, it is feasible to offer some ideas and indeed, the entire investigation can be so time-consuming and can need a great deal of effort from the scientific community worldwide.

\section{Examining functions in a set of real numbers}

Boolean algebra is a part of the set theory that consists of two basic elements: $\{0,1\}$. It seems the binary numbers deal with duality since they can be described as a series of 0 s and 1s. Quantum mechanics suggests that the entire nature deals with duality and oscillates between two basic states, matter and energy. At this stage, it is quite hasty to make any sort of correlations as there is a need for more profound research in both theoretical and empirical manner. The purpose of this effort is to bring forward some brand-new ideas and try to find a link between something already known. In this paper, it is discussed how to design a static absorber which, from the perspective of the field theory, could be regarded as a singularity in the energy field.

Indeed, equations (1) and (2) provide some fundamental steps into such an investigation and, no matter what the inputs are, the output is always nothing. In theory, the absorber could neutralize any power as if some ways of signal conversion were applied. The recommendation is to make as many experimental attempts as possible since their results will help defense industry on its way to produce something that will truly work in practice. As mentioned before, binary algebra deals with two basic states like quantum physics, so in other words - maybe a Boolean analysis can be used for future research and modelling in that area of science.

The real impact of this article will be described under this chapter as it is needed to introduce a completely new approach to binary logics as a fragment of mathematics that needs to deal with some practical applications as well as with a much deeper understanding of its theoretical paradigms. Further, this chapter will introduce how the binary functions can be presented in a set of real numbers making a comparative analysis of the input and output energetic fields. Everything will be illustrated in the 2-D and 3-D coordinate systems trying to encourage prospective researchers to give their contributions. It will be also explained how the previous mathematical models could be transferred in a set of real numbers not giving any analytics of the 
transitional function that could project the elements of the binary logics set into the set of real numbers. For such scientific research it may be necessary to gather a multidisciplinary expert team who would work on such a project for a longer period of time.

Indeed, it is well-known that if equations (1) and (2) are dealt with in the binary set of numbers, such a correlation can give an equation in the real set of numbers as follows:

$$
B=A \cdot(1-A)
$$

where:

$A$ - is an input signal in affirmation that is multiplied with its negation;

$1-A$ - is an inverted input signal that is a negation of the input $A$ which is in the sense of Boolean algebra illustrated as $\bar{A}$; and

$B$ - is an output signal that is a product of affirmation and negation being brought at the inputs.

In any case, the output of equation (5) is 0 which can be described with the truth table as follows:

Table 3 - Truth table of the static absorber

Таблица 3 - Таблица истинности статического абсорбера Табела 3 - Истинитосна тебела статичког апсорбера

\begin{tabular}{|c|c|c|}
\hline A & $1-A$ & $B$ \\
\hline 0 & 1 & 0 \\
\hline 1 & 0 & 0 \\
\hline
\end{tabular}

As illustrated in Table 3, for $A, B \in \square \wedge A, B \in\{0,1\}$, it has been feasible to prove that if the binary values have been taken for the inputs and the output, the result will always be a neutralized function that can be graphically represented in a set of real numbers $\square$ via the graph made in the 2-D and 2-D form using the 3D Grapher tool. These illustrations have been provided in the figures as follows. 


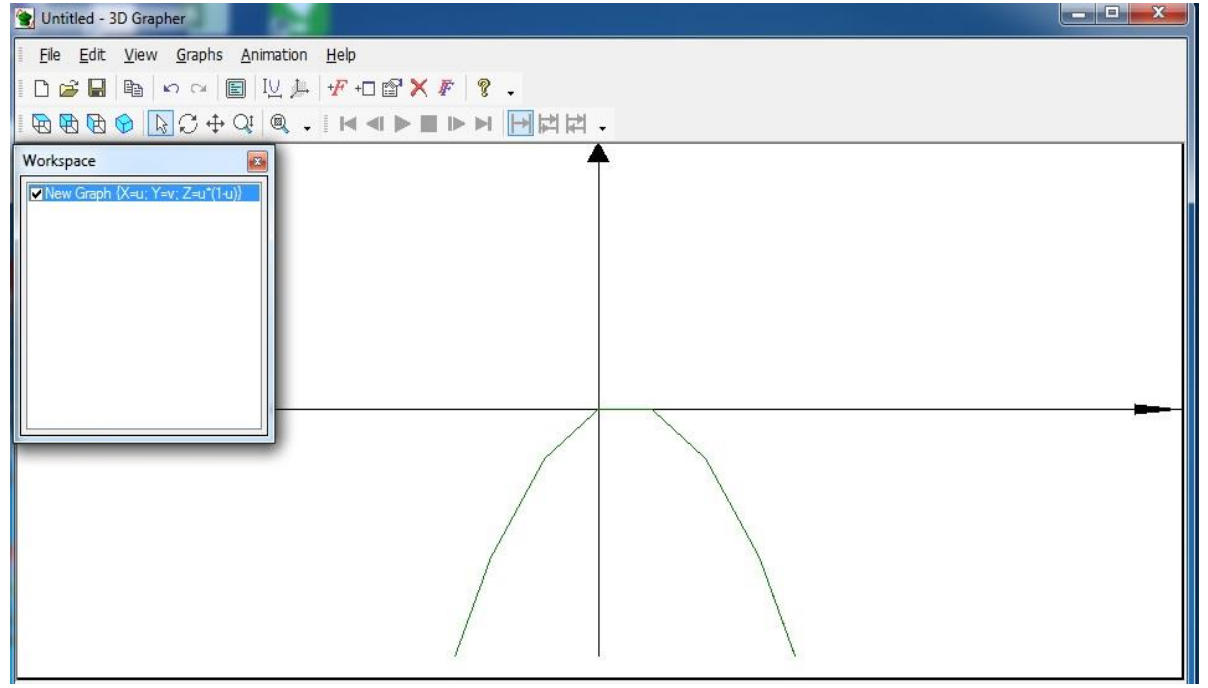

Figure $3-2-D$ graph of equation (5)

Puc. 3-2-Д графрик уравнения (5)

Слика 3-2-Д графрика једначине (5)

Figure 3 shows how equation (5) behaves in the 2-D coordinate system indicating that it is about the square function if $A, B \in(-\infty,+\infty)$.

In other words, in such a case, it is possible to compare a correlation between the input and output signals which can be voltage dealing first, with the values $0 \mathrm{~V}$ and $5 \mathrm{~V}$ as well as the rest of taken variables.

The next illustration in the 3-D surrounding suggests how input and output voltages are dependable on each other. The graphical representation is given in Figure 4 as follows.

Figures 3 and 4 give a closer insight into how equation (5), being the square function in a set of real numbers, behaves in the 2-D and 3-D space. If singular dots behave like a sink in this case, it is quite clear they can be analyzed as a curve as well as an entire surface in the 3-D environment. As explained through this chapter, the AND logic function in Boolean algebra can be represented as a product in a set of real numbers. 


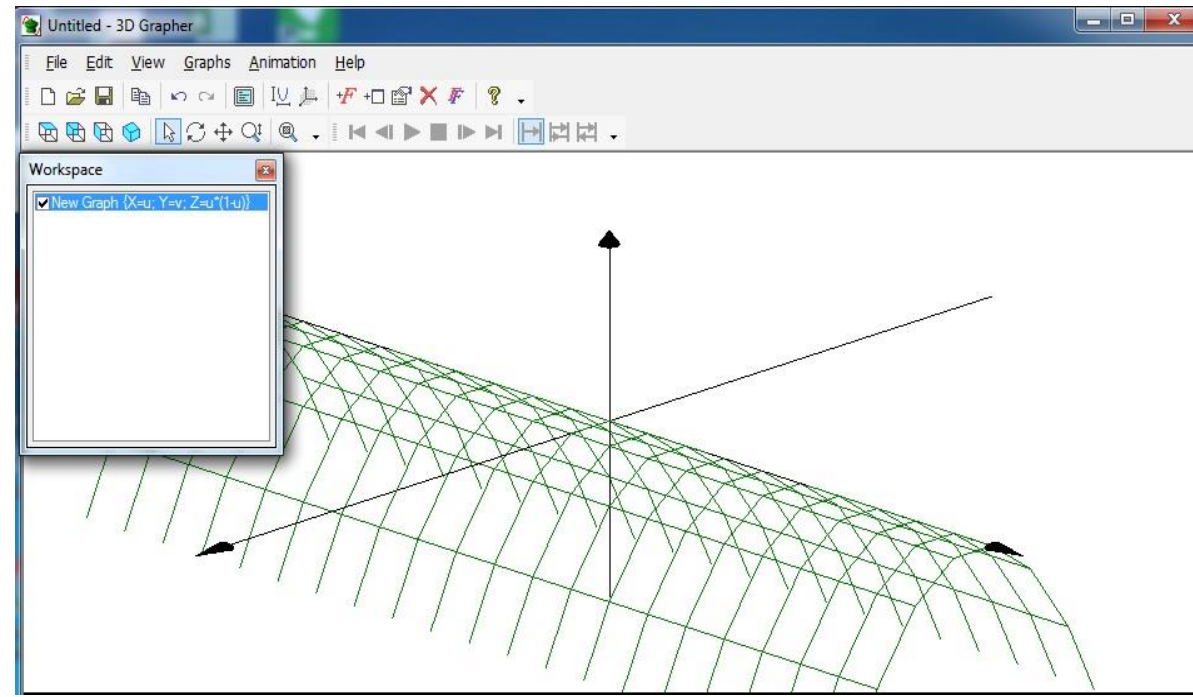

Figure 4-3-D drawing of the singularity surface

Puс. 4- 3-Д рисунок сингулярной поверхности

Слика 4 - 3-Д иртеж сингуларне површине

On the other hand, signals in affirmation and negation are given as described in equation (5). 3D Grapher software deals with the $X-Y-Z$ coordinate system and in this case it is given that $X=u, Y=v$, and $Z=u^{*}(1-$ $u)$. De facto, the true correlation between the inputs and the output would be $X=u, Y=1-u$, and $Z=u^{*}(1-u)$. That means only in such a case it is possible to analyze the behavior of the inputs regarding the outputs.

At this stage, it is sufficient to demonstrate the feasible singularity objects as practically there is only one input being either in affirmation or negation and its unique output deals as given above. The advice for future research is to make an attempt to compare input and output voltages in order to realize how they depend on each other and why such an energetic field neutralizes anything getting close to it.

Further, it is significant to introduce the behavior of equations (3) and (4) in a set of real numbers. Their mathematical model is provided in equation (6) as follows:

$$
C=A \cdot(1-A)+B \cdot(1-B)
$$

where: 
$A$ - is an input which is multiplied with its negation being $(1-A)$ in which case these two inputs give some product as a result;

$B$ - is an input which is multiplied with its negation being $(1-B)$ in which case these two inputs give some product as a result; and

$C$ - is an output of the big function which is in this case a sum of the variables mentioned above.

The truth table of equation (6) is illustrated in Table 4 as follows.

Table 4 - Proof of equation (6) in the truth table

Таблица 4 - Доказательство уравнения (6) в таблице истинности Табела 4 - Доказ једначине (6) у истинитосној табели

\begin{tabular}{|c|c|c|}
\hline A & B & C \\
\hline 0 & 0 & 0 \\
\hline 0 & 1 & 0 \\
\hline 1 & 0 & 0 \\
\hline 1 & 1 & 0 \\
\hline
\end{tabular}

Apparently, it is necessary to illustrate, using 3D Grapher, how equation (6) deals in the 2-D and 3-D space leaving to other researchers to examine the behavior of the input and output energetic fields. At this level, it is enough to demonstrate such a behavior only in the sense of the $X-Y-Z$ coordinate system. The illustration in the 2-D form is given in Figure 5 as follows.

In this case, the 3D Grapher mathematical model includes two inputs and only one output whose correlations are given in Figures 5 and 6 . The model is as follows $X=u, Y=v$, and $Z=u^{*}(1-u)+v^{*}(1-v)$ which can be assumed as a singular area seeking to be better investigated. In total, some initial ideas are given through this effort and there is a huge task for researchers, engineers, and scientists to develop more superior findings for the entire defense industry. 


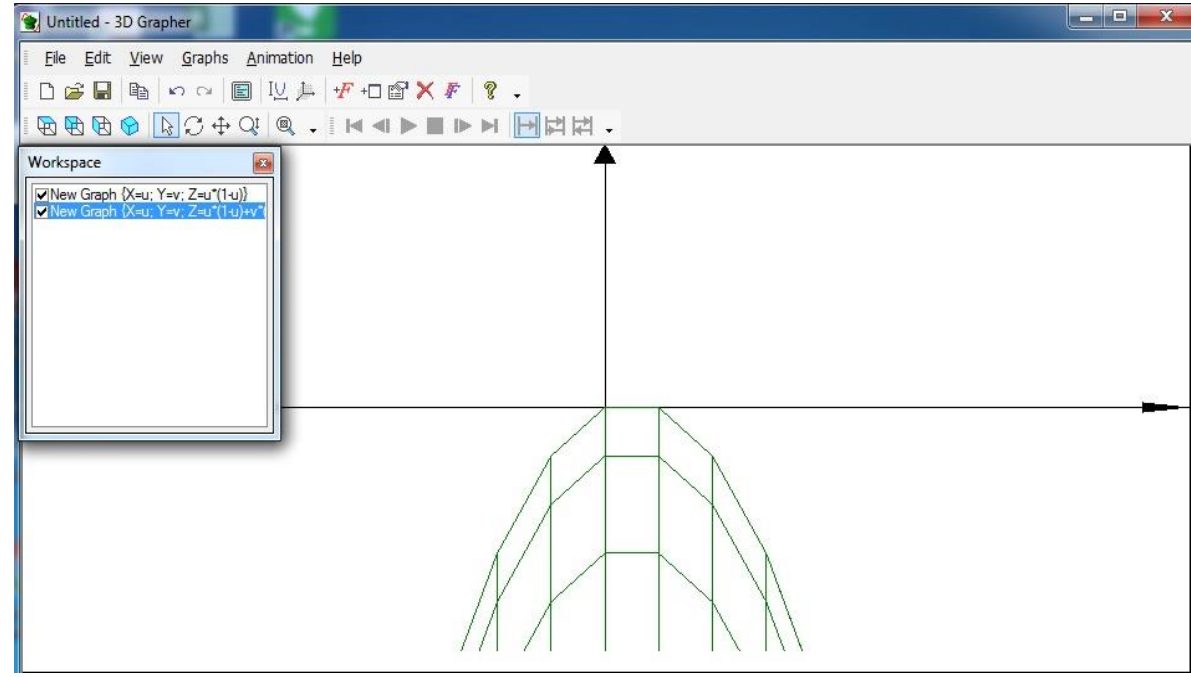

Figure $5-2-D$ behavior of equation (6)

Puc. 5-2-Д поведение уравнения (6)

Слика 5 - 2-Д понашање једначине (6)

On the other hand, the 3-D variation of equation (6) is given in Figure 6 as follows.

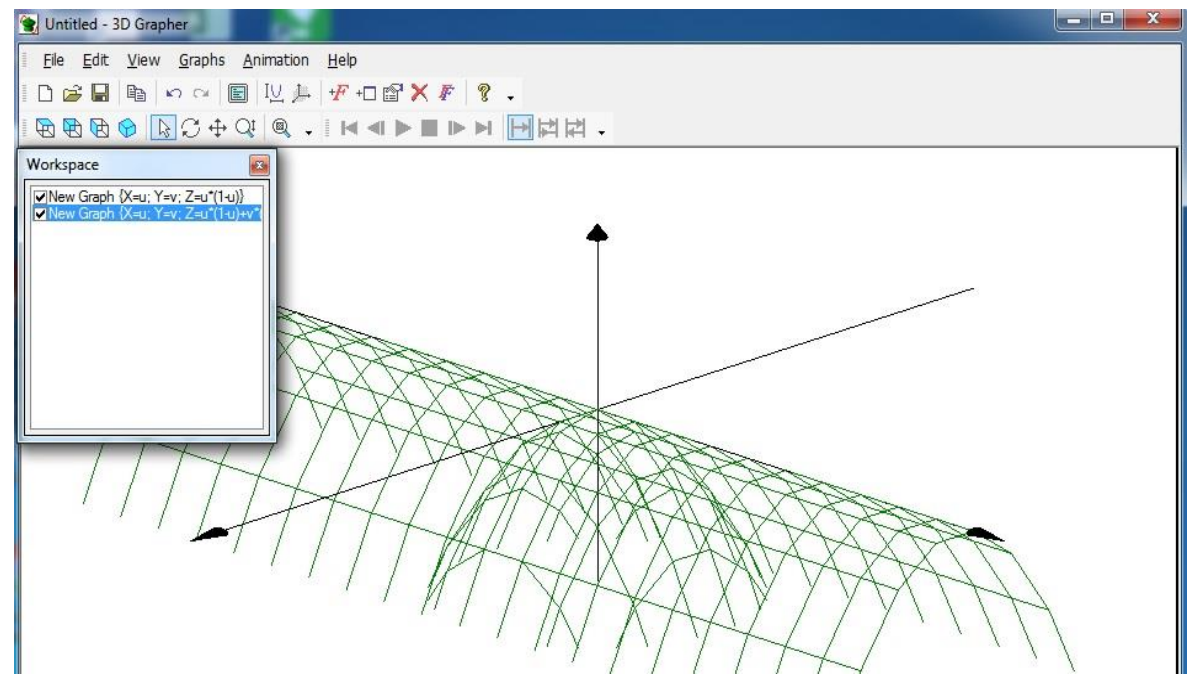

Figure 6-3-D graph of equation (6)

Puc. 6- 3-Д график уравнения (6)

Слика 6- 3-Д графрикон једначине (6) 


\section{Applications in cyber industry}

As it is well known, one of the biggest applications of Boolean algebra is within digital systems and their electronics. The overall computer science and engineering area relies on that mathematical landscape. One of the worst nightmares for any IT security professional is a breach into some IT infrastructure as that can mean loss of data, sabotage or espionage. Entire teams of cyber analysts have been employed 24 hours a day, 7 days a week in order to discover and terminate any attempt to break into protected networks and establish communication between them and the hacker's workstation. (Djekic, 2021f), (Djekic, 2019), (Djekic, 2020a)

The point is, these professionals will need to manage their surveillance capacities and disconnect manually any attempt of a breach. This is called a good incident response. In other words, monitoring software can recognize any anomalies in the cyberspace, but the incident response is not very effective as it is needed to be done manually. The idea of this research effort is to suggest that the effectiveness of the incident response could be improved by simply passing untrusted traffic through a static absorber and terminating it subsequently. The neutralizer would in such a case reject anything being unwanted and the total incident response could take only a few moments. The basic theory of such a concept is given in this paper and if the idea passes some deeper analyses it could find its place in practice. At this stage, it is sufficient to be aware of such simple, but yet powerful abilities of binary numbers.

\section{Conclusion}

This paper discusses some possible capabilities of binary logics suggesting that a static absorber already has some initial modelling, while its dynamic version is still under development. The results given here can trigger an entirely novel research stream when these ideas become empirically verified. Finally, humankind has a skill to handle such superior technology, but the message is to be responsible while doing so.

\section{References}

Djekic, M. 2017. The Internet of Things: Concept, Application and Security. LAP LAMBERT Academic Publishing. ISBN-13: 978-6202096294.

Djekic, M. 2019. The Informant Task. Asia-Pacific Security Magazine, 19 November [online]. Available at: https://www.asiapacificsecuritymagazine.com/the-informant-task/ [Accessed: 1 November 2021]. 
Djekic, M. 2020a. The Importance of Communication in Investigations. International Security Journal, 12 November [online]. Available at: https://internationalsecurityjournal.com/communication-in-investigations/ [Accessed: 1 November 2021].

Djekic, M. 2020b. Detecting an Insider Threat. Cyber Security Magazine, 4 June [online]. Available at: https://cybersecuritymagazine.com/detecting-aninsider-threat/ [Accessed: 1 November 2021].

Djekic, M. 2021a. The Digital Technology Insight. Cyber Security Magazine, 10 October [online]. Available at: https://cybersecuritymagazine.com/the-digital-technology-insight/ [Accessed: 1 November 2021].

Djekic, M. 2021b. Smart Technological Landscape. Cyber Security Magazine, 26 October [online]. Available at: https://cybersecuritymagazine.com/smart-technological-landscape/ [Accessed: 1 November 2021].

Djekic, M. 2021c. Biometrics Cyber Security. Cyber Security Magazine, 26 October [online]. Available at: https://cybersecuritymagazine.com/biometricscyber-security/ [Accessed: 1 November 2021].

Djekic, M. 2021d. Channeling as a Challenge. Cyber Defense Magazine, 17 February [online]. Available at: https://www.cyberdefensemagazine.com/channeling-as-a-challenge/ [Accessed: 1 November 2021].

Djekic, M. 2021e. Communication Streaming Challenges. Cyber Defense Magazine, 16 January [online]. Available at: https://www.cyberdefensemagazine.com/communication-streaming-challenges/ [Accessed: 1 November 2021].

Djekic, M. 2021f. Offense Sharing Activities in Criminal Justice Case. Cyber Defense Magazine, 13 September [online]. Available at: https://www.cyberdefensemagazine.com/offense-activities/ [Accessed: 1 November 2021].

Đekić, M. 2021. The Insider's Threats: Operational, Tactical and Strategic Perspective. LAP LAMBERT Academic Publishing. ISBN-13: 978-620-3-20063-8.

\section{МОДЕЛИРОВАНИЕ СТАТИЧЕСКОГО АБСОРБЕРА}

Милица Д. Джекич

независимый исследователь, г. Суботица, Республика Сербия

РУБРИКА ГРНТИ: 27.00.00 МАТЕМАТИКА:

27.43.17 Математическая статистика

20.00.00 ИНФОРМАТИКА:

20.23.25 Информационные системы с базами знаний

78.00.00 ВОЕННОЕ ДЕЛО:

78.21.49 Военная электроника и кибернетика

ВИД СТАТЬИ: предварительное сообщение 
Резюме:

Введение/цель: В данной статье будет представлен анализ статического абсорбера, который способен нейтрализовать любой сигнал как в физической, так и в виртуальной плоскостях.

Методы: Используемый в статье подход включает в себя исключительно научные рассуждения, а также модель с ее объяснениями, которые были внимательно проанализированы и оценены $c$ помощью высокоразвитых вычислительных инструментов для проектирования и моделирования. Эмпирические результаты к статье не прилагаются, а только утверждения с их доказательствами.

Результаты: Значимым результатом данного исследования является совершенно новый подход к двоичным системам, которые в данном исследовании связаны со множеством действительных чисел.

Выводы: Цель данного исследования заключается в представлении совершенно новой концепции, которая может быть использована в кибериндустрии, в то время как динамический вариант абсорбера все еще находится в стадии разработки.

Ключевые слова: высокотехнологичная безопасность, знания, статический абсорбер, отклонение сигналов, хакерские атаки, сингулярность, математическое моделирование.

\section{МОДЕЛОВАЊЕ СТАТИЧКОГ АПСОРБЕРА}

Милица Д. Ђекић

независни истраживач, Суботица, Република Србија

ОБЛАСТ: бинарна логика, примењена математика, информатика, наменска индустрија, рачунарство, електроника

ВРСТА ЧЛАНКА: претходно саопштење

\section{Сажетак:}

Увод/циљ: Статички апсорбер, чија анализа ће бити приказана у овом раду, у стању је да неутрализује сваки сигнал у физичкој или виртуелној равни. .

Методи: Представљено је искључиво научно размишљање и модел са објашњењима која су пажљиво евалуирана коришћењем софристицираних рачунарских алата за пројектовање и симулацију. Емпиријски резултати нису приложени, већ само тврдње са њиховим доказима. 
Резултати: Најзначајнији резултат овог истраживања јесте потпуно нови приступ бинарним системима који су овде повезани са скупом реалних бројева.

Закључак: Сврха овог истраживања јесте да представи потпуно нови концепт који може да се користи у сајбер индустрији, док је динамичка варијанта апсорбера још увек у фрази развоја.

Кључне речи: високотехнолошка безбедност, сазнања, статички апсорбер, одбијање сигнала, хаковање, сингуларност, математичко моделовање.

Paper received on / Дата получения работы / Датум пријема чланка: 03.11.2021. Manuscript corrections submitted on / Дата получения исправленной версии работы / Датум достављања исправки рукописа: 03.01.2022.

Paper accepted for publishing on / Дата окончательного согласования работы / Датум коначног прихватања чланка за објављивање: 04.01.2022.

(C) 2022 The Author. Published by Vojnotehnički glasnik / Military Technical Courier (www.vtg.mod.gov.rs, втг.мо.упр.срб). This article is an open access article distributed under the terms and conditions of the Creative Commons Attribution license (http://creativecommons.org/licenses/by/3.0/rs/).

() 2022 Автор. Опубликовано в «Военно-технический вестник / Vojnotehnički glasnik / Military Technical Courier» (www.vtg.mod.gov.rs, втг.мо.упр.срб). Данная статья в открытом доступе и распространяется в соответствии с лицензией «Creative Commons» (http://creativecommons.org/licenses/by/3.0/rs/).

() 2022 Аутор. Објавио Војнотехнички гласник / Vojnotehnički glasnik / Military Technical Courier (www.vtg.mod.gov.rs, втг.мо.упр.срб). Ово је чланак отвореног приступа и дистрибуира се у складу са Creative Commons лиценцом (http://creativecommons.org/licenses/by/3.0/rs/). 